\title{
Systematic Assessment of The Development of Innovation Ecosystems in Russian Universities of The Northwestern Federal District
}

\author{
Petrosyants D.V. \\ Financial University under the Government \\ of the Russian Federation \\ Moscow, Russia, \\ National University Ranking-Interfax \\ dan-basa@yandex.ru
}

\author{
Simonov K.V. \\ Financial University under the Government \\ of the Russian Federation \\ Moscow, Russia, \\ ksimonov@mail.ru
}

\author{
Balatsky E.V. \\ Financial University under the Government of the Russian Federation \\ Moscow, Russia, \\ ebalatsky@inbox.ru
}

\begin{abstract}
The article analyzes the current level of development of Russian universities located in the Northwestern Federal District (NWFD), examines various aspects of their activities, and searches for an adequate comprehensive assessment of the effectiveness of a modern university that meets the standards of the best world practices. As part of the research of the National University Rating Interfax (NUR-Interfax) analytical group, an information base has been accumulated on a number of indicators of Russian universities. Some observations from the analysis of the NUR-Interfax rating databank are presented in this paper. Within the framework of the restart of the National Projects (NP) in 2019-2024, it is planned to merge NP Science and NP Education into a single NP that has an almost well-established name "Science and Universities". The project aims at continuity in the development of the higher education system in the Russian Federation. The most attention in the regions of Russia should be given to the creation of so-called "belts of innovative enterprises" around the leading regional university. The universities themselves, in turn, should clearly define priorities and create realistic and promising development programs in order to produce the effect of a "snowball of progress" in the university to attract all types of resources, not only material, but also human. The development of higher education should follow and correspond to the global trends in the development of the 21st century university. However, the features of the socio-political and economic development of the Northwestern Federal District, primarily the level of the actual development of universities and their geographical location, should be taken into account.
\end{abstract}

Keywords-academic rankings, transformation of higher education, universities, peer reviews, scientometrics.

\section{INTRODUCTION}

To a large extent, the analysis of the development of the university through various criteria-based assessments and statistical indicators is an outside perspective. After all, it is only possible to evaluate the completeness and success of practices and identify the problems of the development of a modern university locally from one or another limited perspective.

However, in many respects, the external reflection of the scientific, educational and expert community can influence the effectiveness of the university's representation in the information and communication space, and practically influence the recognition and media weight of the university brand. In this article, we would like to present certain assessments and directions of development of universities of Northwestern Federal District (NWFD) that fit the trendy modern concept of an ecosystem of innovations [1-3]

In total, over 200 higher educational institutions operate in the Northwestern Federal District, including branches (in our study, we will rely on data collected from the most prominent and high-profile universities included in the National University Rankings project in 2020). Among them, the leading positions are occupied by universities located in St. Petersburg. In addition, there are two high-profile federal universities in the federal district. Moreover, they are completely different and independent in their concept of development. A total of 39 universities in the Northwestern Federal District were represented in the NRU-Interfax ranking. Of these, in addition to the two federal universities mentioned 
above, there are four national research and six key universities on the territory of the Northwestern Federal District, and four of them are participants in the 5-100 project that is being completed in 2020.

What are the main directions of development of universities in the Northwestern Federal District? Is there a common basis in their interaction with each other and in other collaborations with Russian and foreign universities? Is it possible to plunge into the socio-economic and political agenda, creating a belt of innovative enterprises around itself? We will not answer these questions in this article, but we will try to offer an effective mechanism for measuring certain indicators characterizing the development of universities. And of course, we must definitely check the direction of development of the universities of the Northwestern Federal District with the program of strategic academic leadership (SALP).

\section{METHODOLOGY AND SOURCES OF INFORMATION}

As part of the research of the analytical group National University Rating Interfax (NUR-Interfax), an information base has been accumulated on a number of indicators of Russian universities. Some observations from the analysis of the NUR-Interfax rating databank are presented in this paper. This methodology involves the study of the development of universities in six separate analytical blocks, which are not autonomous from each other, but contain aggregated information on the directions of development of higher education (Fig. 1) [4].

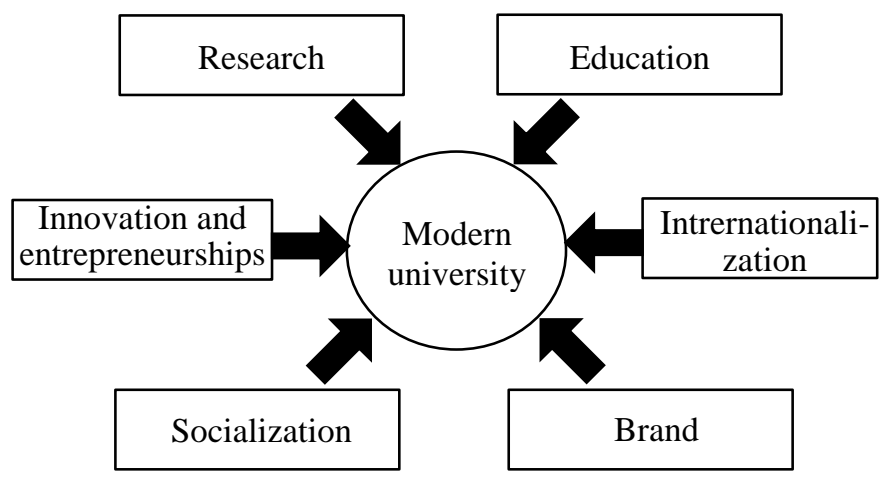

Fig. 1. Integral blocks of modern university development

In addition, the sources of information for this work were open pieces of data from the official websites of Russian universities, websites of Russian government agencies, articles from journals, including those indexed in WoS and Scopus, as well as the Russian Scientific Electronic Library (RSCI) in accordance with the Open Science paradigm. In the process of working on the article, a number of articles by Russian and foreign authors on the development of universities in the Northwestern Federal District were analyzed [5-17].

The authors used data from the websites of the following organizations:
- information and analytical materials based on the results of monitoring the effectiveness of the activities of educational institutions of higher education / Website of the Ministry of Science and Higher Education of the Russian Federation (MSHE RF). Main Information and Computing Center (http://indicators.miccedu.ru/monitoring/?m=vpo);

- the official website of the Ministry of Science and Higher Education of the Russian Federation (MSHE). National Education Project (https://edu.gov.ru/nationalproject);

- the official website of the State Statistics Committee of the Russian Federation (http://www.gks.ru);

- abstract base of scientific publications Scopus (http://www.scopus.com);

- Russian Science Citation Index (RSCI) (http://www.elibrary.ru.);

- SCAN-Interfax. Monitoring of Russian media and analysis of the media environment (http://scaninterfax.ru);

- the official website of the project Academy Interfax / National University Ranking (NUR-Interfax) (http://academia.interfax.ru).

We used a set of traditional research methods, including classification, comparative analysis, generalization, comparison and forecasting.

The reliability of the results was ensured by comparing data from different sources and use of data validation methods: coefficient of variation, mean absolute deviation, range of variation, indicators of asymmetry and kurtosis.

\section{FINDINGS}

Within the framework of the restart of the National Projects (NP) in 2019-2024, it is planned to merge NP Science and NP Education into a single NP that has an almost well-established name "Science and Universities". The project sets as its task the continuity in the development of the higher education system in the Russian Federation. It is focused on several key positions:

- integration of Russian universities into the global research space;

- research leadership in a number of priority areas;

- development of scientific and educational competitive infrastructure based on digital technologies;

- staffing in accordance with the needs of the modern economy.

The Strategic Academic Leadership Program (SALP) provides for a revision of the previously assigned statuses of national research (NRU) and national key universities (NKY). In addition, all Russian universities will be categorized by formal indicators. 


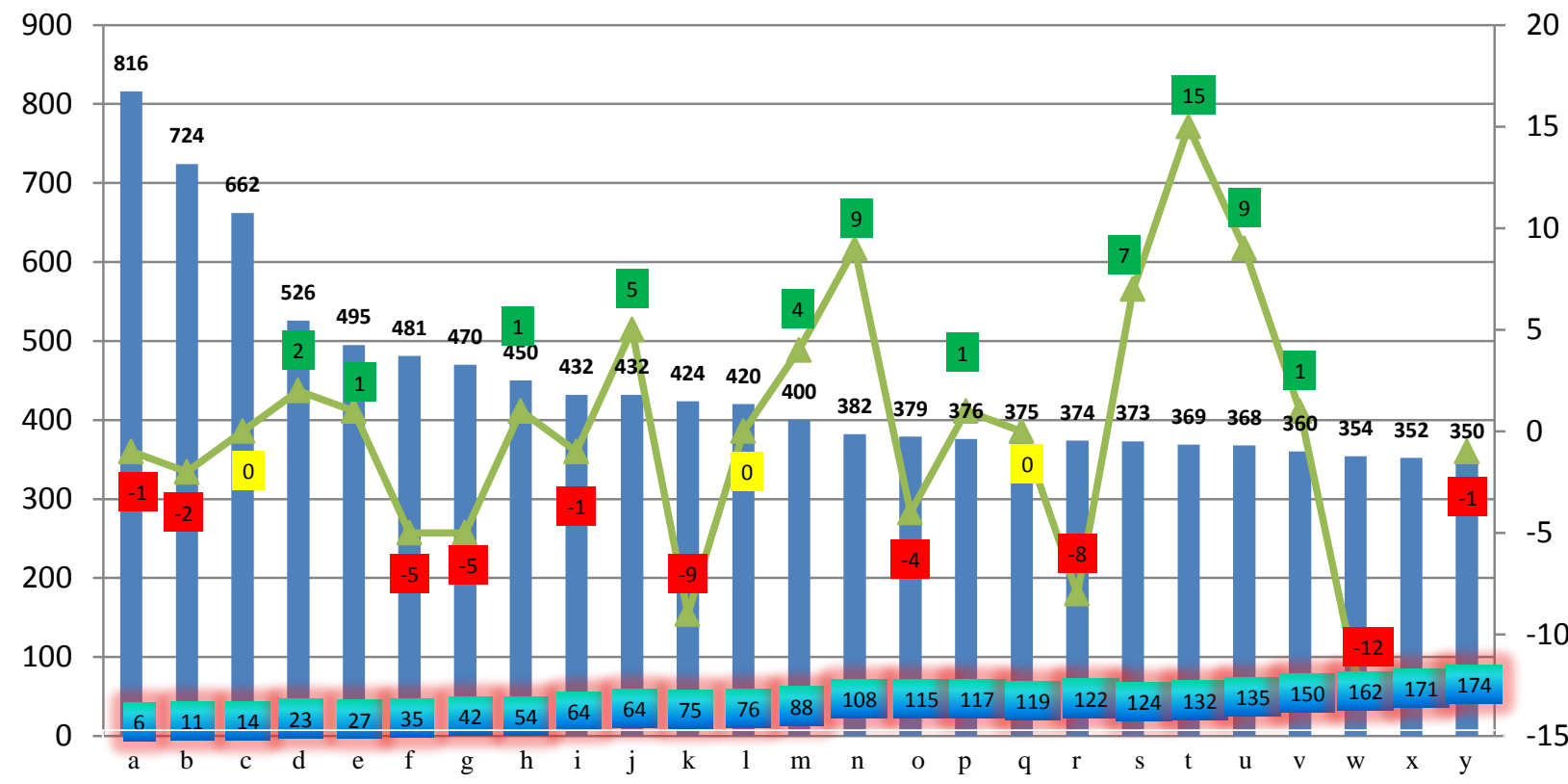

Fig. 2. National University Ranking 2020. Universities of the Northwestern Federal District: dynamics of positions for the year. Top 25. Source: compiled by the authors according to NUR 2020

a - SPbU; b - ITMO; c - SPbPU; d - SPMU; e - PeterSU; f - IKBFU; g - LETI; h - NWSMU; i - UNECON; $\mathrm{j}$ - Herzen University; $\mathrm{k}$ - NArFU; 1 - PSTU; m - SPbSUT; $n$ - SPBAU; o - Pavlov University; $\mathrm{p}$ - SPbSUITD; $\mathrm{q}$ - SUAI; $\mathrm{r}$ - SPSPMU; $\mathrm{s}$ - SPCPA; $\mathrm{t}$ - ChSU; $\mathrm{u}$ - NSMU; $\mathrm{v}$ - SyktSU; $\mathrm{w}$ - SMTU; $\mathrm{x}$ - SPSUACE; $\mathrm{y}$ - NovSU

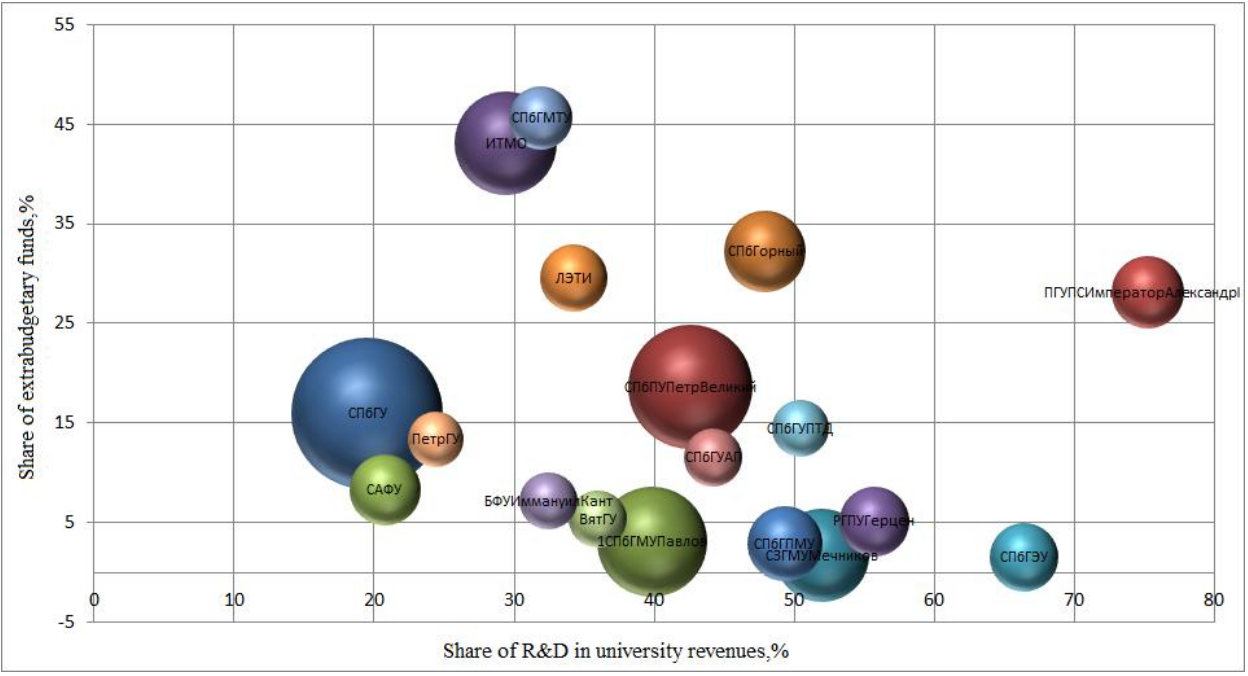

Fig. 3. The budgets of the universities of the Northwestern Federal District (billion rubles) and the share of revenues from extrabudgetary sources and R\&D in them in 2018,\%. Source: compiled by the authors according to the Russian Ministry of Education and Science

It is possible, along with other options, for university to enter into the SALP through participation in a consortium that will be created by other universities to participate in the competition. In fact, SALP focuses on the development of the university, REC - on the development of the region $[18,19]$.
At the end of July 2020 , the 11 th edition of the annual National Rating was released universities - Interfax (NUR). 


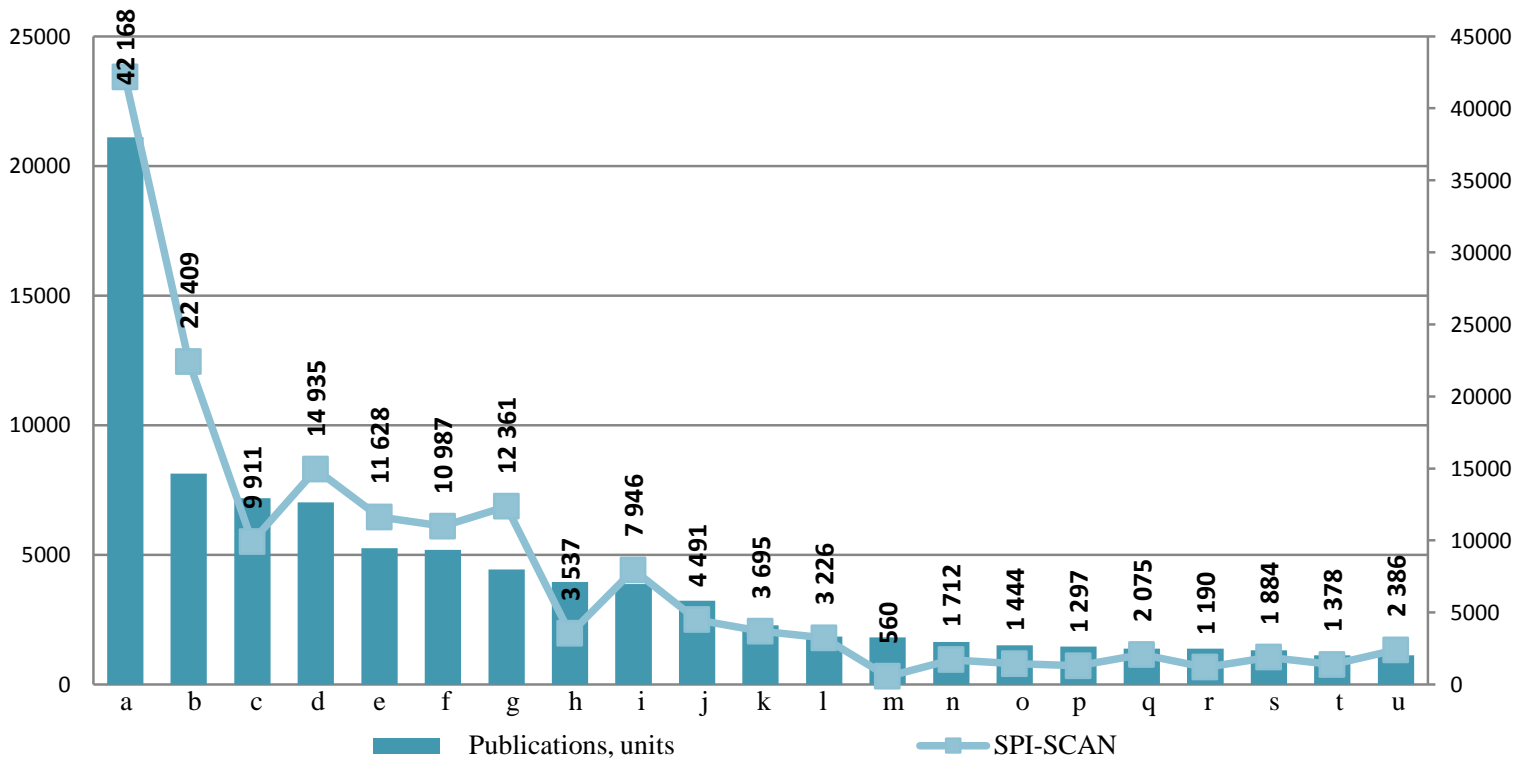

Fig. 4. The number of publications and citations of scientists affiliated with the universities of the Northwestern Federal District by the cumulative total in the Scopus database, February 2019

a - SPbU; b - ITMO; c - SPbPU; d - NArFU; e - IKBFU; f - PeterSU; g - SPMU; $h$ - Herzen University; i - PskovSU; j - SyktSU; $k$ - UNECON; 1 - PSTU; $\mathrm{m}$ - VSU; $\mathrm{n}$ - LETI; o - KSTU; $\mathrm{p}$ - USTU; $\mathrm{q}$ - NSMU; $\mathrm{r}$ - MASU; $\mathrm{s}$ - ChSU; $\mathrm{t}$ - SPbSUT; $\mathrm{u}$ - MSTU

It presents a wide and varied spectrum of universities in the Northwestern Federal District, from well-known and historical universities of St. Petersburg to young regional ones; from classical universities to universities with their own specifics (pedagogical, medical, academic, etc.). In addition, in Fig. 2, we present the movements of universities in the ranking from 2019 to 2020 , which is quite correlated with the indicators that are used in the research methodology. The universities of St. Petersburg are in the leading positions among the universities of the Northwestern Federal District, federal universities occupy the 6 and 11 positions (Immanuel Kant Baltic Federal University and Northern (Arctic) Federal University named after M.V. Lomonosov, respectively).

A comprehensive analysis of the development of universities in the Northwestern Federal District was carried out recently in the refraction of two vectors: performance monitoring and rating assessments of foreign and Russian rankers [20]. Not everything can be measured, but the importance of a strong regional university is characterized primarily by its human resources, the quality of research, immersion in the development agenda of the region / macroregion, and all the manifestations that contribute to the socialization of persons affiliated with the university.

Now let's turn to some metrics and indicators that characterize the status quo that defines this research and allows universities to be evaluated from different angles.

Fig. 3 presents data on the volume of budgets of universities in the Northwestern Federal District. Here we can estimate the share of revenues in the budgets of the universities of the Northwestern Federal District received from $\mathrm{R} \& \mathrm{D}$, as well as the relative volume of revenues received from extra-budgetary sources.

Fig. 4 presents data on the publication activity of the universities of the Northwestern Federal District, also as an accumulated result, which demonstrates the historical superiority in the representation of large universities of St. Petersburg in this database. A more in-depth analysis shows that the universities of the Northwestern Federal District also did not escape the problems that all Russian universities face. The task has been set to improve scientometrics at any cost, so all the signs of "inflation" of the result manifest: participation in "dubious" joint publications, purchase of whole issues of so-called "junk" foreign journals, often already excluded from Scopus and Web of Science systems, etc. So the number of publications and their citations is growing at a very fast pace, but the quality and scientific value of these works, at least some of them, are worth doubting.

Speaking about the brand of the university, one cannot ignore the indicators of publication activity in the open information space, which also shows the visibility of the university, the position of its employees on a number of issues, the university's involvement in the socio-economic and political life of the country and the region, etc. (Fig. 5). Aggregated measurements of media presence in the media show a huge advantage of $\mathrm{SPbU}$ in comparison with other universities in the region.

\section{CONCLUSION}

As a result of our research, we have formulated a number of conclusions.

The reformatting of the 5-100 program and the implementation of a new project of strategic academic leadership (SALP), of course, will not ignore the Northwestern Federal District. Universities will actively integrate into the new national project "Science and Universities", which will require a revision and clarification of strategic programs for the development of universities, synchronization with the tasks of the subjects of the Russian Federation and the federal district as a whole. 


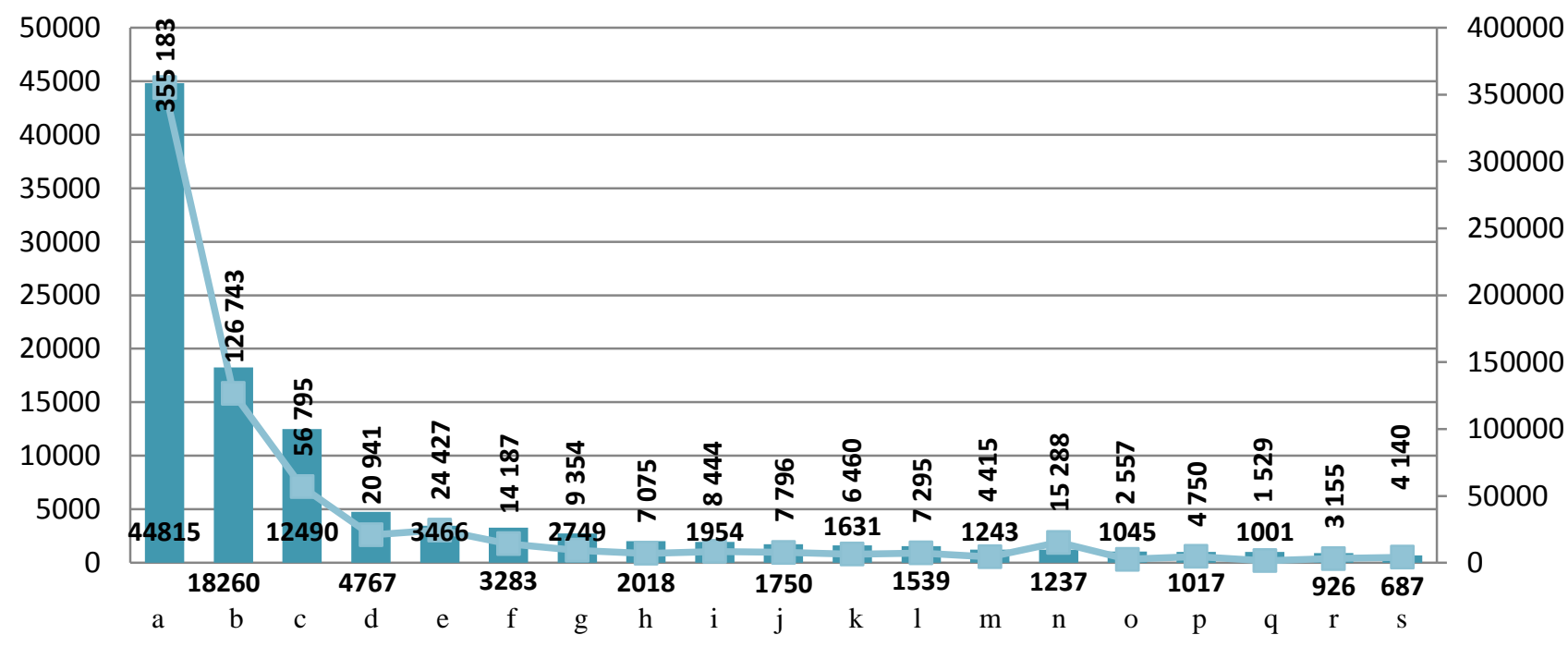

Publications, $2019 \longrightarrow$ Citations

Fig. 5. Publication activity of the universities of the Northwestern Federal District according to SCAN-Interfax in 2018

a - SPbU; b - SPbPU; c - ITMO; d - LETI; e - Pavlov University; f - SPSIT; g - SPMU; h - IKBFU; i - Herzen University; j - NWSMU; k - PeterSU; 1-SUAI; $\mathrm{m}$ - SPbSPU; $\mathrm{n}$ - Shrawlers; o - Spbgutd; $\mathrm{p}$ - SPbSUT; $\mathrm{q}$ - NArFU; $\mathrm{r}$ - SPCPA; s - SMTU

A prerequisite for participation in SALP will be the formation of consortia by universities, both NRU and PEI, together with scientific organizations, companies of the real sector of the economy, primarily high-tech, as well as with other universities that are not geographically close.

For PEI, it is still impossible to limit itself to the research space of only its own region (macroregion), while there is no contradiction with the establishment of regional orientation and the need to train personnel only for the regional economy. Some of the issues should be transferred to the plane of a more competent use of the mechanism of scientific collaborations, but here a lot will depend on the direction of the work of various scientific teams, connection to the world "scientific fronts" and compliance with the world level of research. Practically it

Foresight of university development programs, their revision and adjustment no later than six months or a year, despite the long-term framework of the adopted concepts, is an urgent need today, because in about five years the skills of specialists, not only in the field of high technologies, go through half of their "life cycle". In other words, in five years from enrollment to graduation, the value of his/her education will decrease by $50 \%$. This means that the university should play, if not ahead of the curve, then at least with a minimal lag.

The development of human capital (potential) in the regions of the country is a complex process that requires coordination of interests both in the center-region vector and in the interaction of institutions of an innovative market economy. For the Russian regions, the problem of brain drain to Moscow, St. Petersburg and other large cities, as well as to foreign countries, is urgent. It is possible to stop this process only by developing appropriate conditions in the regions, creating an appropriate institutional environment, competitive not only by Russian but also by world standards. In most regions of the country, trained and graduated specialists (masters, bachelors, postgraduates, etc.) in accordance with the federal planned figures, cannot be employed in their regions, due to the lack of a sufficient number of highly qualified jobs. The mechanism for developing students' readiness for scientific and innovative activities in most Russian universities is not fine-tuned. Despite the existence of a number of programs for the development of small and medium-sized businesses in the Russian Federation, the number of such structures is currently decreasing, the involvement of students and other students is small.

For the most part, complex program tasks should become a fundamental development goal for strong Russian universities, under which the university's innovation ecosystem will be built, and development programs for the medium and long term will be formulated. Great attention should be paid to the creation of so-called "belts of innovative enterprises" around the leading regional university in the regions of Russia, and the universities themselves, in turn, should clearly define priorities and create real promising development programs in order to produce the effect of a "snowball of progress" in the university to attract all types of resources, not only material, but also human.

Only harmonization of interests and joint efforts of the scientific and educational community, government agencies and domestic high-tech business can lead to synergy in the development of an ecosystem of innovations in Russian universities.

Most of the methods have significant drawbacks, but even greater problems lie in the complexity of data verification and standardization of the calculations of the estimated indicators of the multifactorial activity of the university. In many respects, this is also the problem of monitoring the 
effectiveness of MSHE, with an understandable desire to measure parameters (criteria) that do not have a solid methodological basis, they have to not be applied at all.

For an effective and prompt assessment of the modern development of the innovative and entrepreneurial environment in Russian universities, it is necessary to develop a universal multi-criteria methodology, some of the directions in the development of which we have considered in this article.

\section{Acknowledgments}

The article was prepared with the financial support of the Russian Foundation for Basic Research, project no. 19-01000104 "System regulation of the development of innovation ecosystems in the leading Russian central and regional universities".

\section{References}

[1] P.G. Altbach, "Advancing the national and global knowledge economy", The role of research universities in developing countries Studies in Higher Education, 2013, vol. 38(3), pp. 316-330. DOI: https://doi.org/10.1080/03075079.2013.773222

[2] D. Salmi and I.D. Frumin I.D., "How States Achieve The International Competitiveness Of Universities: Lessons For Russia", Educational Issues, 2013, vol. 1, pp. 025-068.

[3] I.D. Frumin and O.V. Leshukov, "Typology Of Regional Systems Of Higher Education In Russia”, Federal'nyj spravochnik. Obrazovanie v Rossii, M.: ANO «Centr strategicheskih programm», 2016, vol. 11

[4] D.V. Petrosyants, V.V. Zubenko, P.S. Seleznev and I.V. Arzhanova, "Increasing The Competitiveness Of Universities In The North Caucasus Federal District In Synchronization With The Tasks Of Regional Development", Higher education in Russia, 2020, vol. 29(5), pp. 22-33 DOI: https://doi.org/10.31992/0869-3617-2020-29-5-22-33

[5] E.V. Kudryashova and S.E. Sorokin, "The Third Mission" In The Development Programs Of Russian Universities (On The Example Of Universities In The North-West Federal District)", Znanie. Ponimanie. Umenie, 2019, vol. 4. DOI: 10.17805/zpu.2019.4.6

[6] G.S. Drori, G. Delmestri and A. Oberg, "The Iconography Of Universities As Institutional Narratives", Higher Education, 2016, vol. 71(2), pp. 163-180. DOI: 10.1007/s10734-015-9894-6

[7] F.R. van der Ploeg, R. Veugelers, "Towards Evidence-Based Reform Of European Universities", CESifo Economic Studies, 2008, vol. 54(2), pp. 99-120. DOI: 10.1093/cesifo/ifn015

[8] I.V. Slobodchikova, V.V. Bojaeva and V.S. Goldenova, "A modern university as a subject of sustainable development of a region in an innovative economy”, Bulletin of SevKavGTI, 2014, vol. 17, pp. 42-46. (in Russ.).

[9] C. Guccio, M.F. Martorana and I. Mazza, "Efficiency Assessment And Convergence In Teaching And Research In Italian Public Universities", Scientometrics, 2016, vol. 107(3), pp. 1063-1094. DOI: 10.1007/s11192-016-1903-8

[10] F.L. Collins and G.S. Park, "Ranking And The Multiplication Of Reputation: Reflections From The Frontier Of Globalizing Higher Education", Higher Education, 2016, vol. 72(1), pp. 115-129. DOI: 10.1007/s10734-015-9941-3

[11] C.V. Verkhovets, V.I. Kirko and A.V. Keush, "The role of federal universities in the formation of regional innovation infrastructure (case study of the Siberian Federal University)", Innovation, vol. 10, pp. 6064. (in Russ.)

[12] A.O. Karpov, "Is University 3.0 Possible In Russia?", Sociological studies, 2018, vol. 9(413), pp. 59-70. DOI: $10.31857 / \mathrm{S} 013216250001959-7$

[13] G.A. Klyucharev and A.V. Neverov, "Project "5-100": Some Interim Results", Vestnik Rossijskogo universiteta druzhby narodov, Seriya: Sociologiya, vol. 18(1), pp. 100-116. DOI: 10.22363/2313-2272-2018$18-1-100-116$

[14] E. Uyarra, "Conceptualizing The Regional Roles Of Universities, Implications And Contradictions", European Planning Studies, 2010, vol. 18(8), pp. 1227-1246. DOI: 10.1080/09654311003791275

[15] R. Pinheiro, P. Benneworth and G.A. Jones, "Understanding Regions And The Institutionalization Of Universities", Universities and Regional Development: A Critical Assessment of Tensions and Contradictions, 2012, pp. 11-32. DOI: $10.4324 / 9780203112298$

[16] G.A. Klyucharev and A.V. Neverov, "Project "5-100": Some Interim Results", Vestnik Rossijskogo universiteta druzhby narodov. Seriya: Sociologiya, 2018, vol. $18(1)$, pp. 100-116. DOI: 10.22363/2313-22722018-18-1-100-116

[17] O.A. Denisova and O.L. Lekhanova, "Best Practices Of Inclusive Higher Education In Universities Of The Northwestern Federal District", Vestnik Cherepoveckogo gosudarstvennogo universiteta, 2018, vol. 6(87), pp. 156-169.

[18] D.A. Endovitsky, V.V. Korotkikh and M.V. Voronova, "Competitiveness of Russian Universities in the Global System of Higher Education: Quantitative Analysis", Vysshee obrazovanie v Rossii, 2020, vol. 29(2), pp. 9-26. DOI: 10.31992/0869-3617-2020-292-9-26

[19] P.A. Zhdanov, N.A. Polikhina, E.Yu. Sema, L.V. Kazimirchik, I.B. Trostyanskaya and A.A. Barsukov, "Network Analysis Of The Degree Of Integration Of Project "5-100" Universities Into The International Educational Space", Vysshee obrazovanie v Rossii, 2019, vol. 28(11), pp. 155-167. DOI: 10.31992/0869-3617-2019-28-11-155-167

[20] E.A. Yanova and M.V. Valdaitseva, "Assessment of the system of performance indicators of multidisciplinary universities", Ekonomicheskie nauki, 2019, vol. 172. pp. 90-99. 